NBER WORKING PAPER SERIES

\title{
CONTRACEPTION AS DEVELOPMENT? NEW EVIDENCE FROM FAMILY PLANNING IN COLOMBIA
}

\author{
Grant Miller \\ Working Paper 11704 \\ http://www.nber.org/papers/w11704 \\ NATIONAL BUREAU OF ECONOMIC RESEARCH \\ 1050 Massachusetts Avenue \\ Cambridge, MA 02138 \\ October 2005
}

I am indebted to David Cutler as well as David Bloom, Ken Chay, and Richard Frank for their advice and support. Hoyt Bleakley, David Canning, Erica Field, Amy Finkelstein, Sendhil Mullainathan, Joe Newhouse, Ben Olken, Cristian Pop-Eleches, Piedad Urdinola, Alan Zaslavsky, and seminar participants at Harvard, Johns Hopkins, RAND, Stanford, University of Chicago, University College London, University of Colorado at Boulder, and University of North Carolina at Chapel Hill made helpful suggestions at various stages of this research. Gonzalo Echeverry, Angela Gomez, and especially Gabriel Ojeda at PROFAMILIA were generous with their time and knowledge throughout this project. Cesar Caballero and staff at the Departamento Administrativo Nacional de Estadistica (DANE) graciously provided the Colombian population censuses and other statistics, as facilitated by Mercedes Borrero. Dan Feenberg and Mohan Ramanujan made extra-ordinary computing resources available. The views expressed here are not necessarily the views of PROFAMILIA or its staff. Research support from the National Institute on Aging (grant number T32 AG00186) through the National Bureau of Economic Research (NBER) is gratefully acknowledged. All errors are my own. The views expressed herein are those of the author(s) and do not necessarily reflect the views of the National Bureau of Economic Research.

(C2005 by Grant Miller. All rights reserved. Short sections of text, not to exceed two paragraphs, may be quoted without explicit permission provided that full credit, including $\odot$ notice, is given to the source. 
Contraception as Development? New Evidence from Family Planning in Colombia

Grant Miller

NBER Working Paper No. 11704

October 2005, Revised June 2006

JEL No. I12, I31, J13, N36, O12

\begin{abstract}
$\underline{\text { ABSTRACT }}$
There has been considerable debate in the last decade about whether or not family planning programs in developing countries reduce fertility or improve socioeconomic outcomes. This paper provides new evidence on the role of contraceptive supply by exploiting the surprisingly haphazard expansion of one of the world's oldest and largest family planning organizations - PROFAMILIA of Colombia. It finds that family planning was responsible for only $10 \%$ of the decline in fertility during Colombia's demographic transition. As in developed countries, however, lowering the costs of postponing first births produced important socioeconomic gains, enabling young women to obtain substantially more education and to work more and live independently later in life.

Grant Miller

CHP/PCOR

Stanford University

117 Encina Commons

Stanford, CA 94305-6019

and NBER

ngmiller@stanford.edu
\end{abstract}


"The goal is not reducing, increasing, or stabilizing the numbers of people. It is helping make more possible a richer, fuller life - jobs; homes; resources; freedom from hunger, disease, ignorance; time for development of innate capacities - in short, enriching the quality of life for an increasing proportion of the world's people."

- Leona Baumgartner, USAID, 1965

(at the launch of USAID's population assistance program ${ }^{1}$ )

\section{Introduction}

Family planning programs have been a part of development agendas for nearly half a century. ${ }^{2}$ Without access to modern contraceptives, the costliness of fertility control was historically thought to cause vicious cycles of high fertility, poverty, and economic stagnation (Ehrlich and Holdren 1971, Ehrlich and Ehrlich 1990). However, beliefs about the importance of family planning in development are at times stronger than the evidence that supports them. In particular, because the placement and utilization of family planning programs are generally related to the demand for children, rigorous evaluations have proven to be difficult (Pritchett 1994, Schultz 1994 and 2005). ${ }^{3}$

As this shortcoming has become better recognized, a very different view has gained prominence in the last decade: development simply causes women to want fewer children, and the true effect of contraceptive supply on fertility is quantitatively unimportant (even if large reductions in fertility are achieved with modern contraceptives) (Pritchett 1994, Bongaarts 1994, Dasgupta 1995). This controversial demand-oriented view requires either (a) that the demand for

\footnotetext{
${ }^{1}$ USAID has been a principal supporter of PROFAMILIA.

${ }^{2}$ Family planning programs are a bundle of services that generally aim to reduce the costs of fertility control. They typically include the provision of contraceptive services and devices as well as reproductive education.

${ }^{3}$ Even the results of the famous Matlab family planning experiment (Phillips et. al. 1988, Koenig et. al. 1992, Foster and Roy 1997, Sinha, 2003) have been called into question. First, there is new evidence that true randomization was not achieved (Joshi and Schultz 2005). Second, the family planning treatment was too expensive to be financially sustainable without considerable external support - program expenditures per fertile women and per averted birth were roughly $10 \%$ and $120 \%$ of per capita GDP (thirty-five times more than mean family planning spending per capita in other Asian countries at the time) (Pritchett 1994). Third, health services were integrated into the family planning treatment four years after the experiment began, making it difficult to isolate the consequences of family planning.
} 
children very price inelastic, or (b) that the costs of fertility control are small or are not shifted much by family planning. Although price elasticity of demand for children is not well established, both experience with HIV/AIDS prevention and empirical research on intrahousehold bargaining suggest that the costs of fertility control may be large in the absence of modern contraceptives. ${ }^{4}$ Moreover, debate about family planning and lifetime fertility often overlooks other important dimensions of fertility and well-being emphasized in wealthy country studies - the timing of first births and human capital accumulation, for example (Angrist and Evans 1998, Goldin and Katz 2002, Miller 2005, Bailey 2006).

In this paper, I provide new evidence on the role of contraceptive supply in development drawn from one of the world's oldest and largest family planning organizations - PROFAMILIA of Colombia (Asociacion Pro-Bienestar de la Familia Colombiana). PROFAMILIA was founded in 1965 under an informal political compromise and became the country's dominant family planning provider for thee decades. Several key features of its programs allow me to address the difficulties of previous research: their massive country-wide coverage, their duration over several decades, their financial sustainability, and their remarkably haphazard geographic spread. This last feature provides variation in contraceptive supply not related to demand. Figure 1 provides suggestive evidence of PROFAMILIA's impact. Fertility declined more abruptly in Colombia than in any other South American country over any period of time precisely as it was scaling-up its operations during the late 1960s and early 1970s.

PROFAMILIA was founded during a period of unprecedented social and economic change in Colombia, so an empirical strategy capable of isolating its impact is critical. Because

\footnotetext{
${ }^{4}$ The challenges of HIV/AIDS prevention suggest little deviation from desired sexual activity even if the consequences are grave (Gertler, Shah, and Bertozzi 2003, United Nations Program on HIV/AIDS 2004). Women in developing countries also thought to have relatively little bargaining power within households (Thomas 1990 and 1994, Case and Deaton 1998, Pitt and Khandker 1998, Duflo 2003, Rangel 2004), so negotiating sexual activity and fertility choices with men may be quite costly.
} 
the introduction of its programs varied across municipalities and over time, variation in contraceptive access among women of the same age in different municipalities and among women of slightly different ages in the same municipality can be combined to estimate family planning effects. Other studies have used similar approaches, but they have generally found that programs were established in response to changes in need or prosperity (i.e., demand) (Rosenzweig and Wolpin 1986, Pitt, Rosenzweig, and Gibbons 1993, Gertler and Molyneaux 1994). ${ }^{5}$ This does not appear to be the case with PROFAMILIA.

I first investigate the effects of family planning on lifetime fertility. My findings suggest that the availability of modern contraceptives allowed women to postpone their first birth and to reduce their completed lifetime fertility by $6 \%$ to $13 \%$ (two-fifths to three-quarters of a child). However, these estimates explain only about $10 \%$ of the fertility decline in program areas between 1964 and 1993, suggesting other factors (although not necessarily demand-side factors) to be more important determinants of women's lifetime fertility.

Next, I estimate program effects on women's socio-economic status. Women with access to family planning at all fertile ages received nearly 0.15 more years of schooling, were more likely to work in the formal sector, and were less likely to live with male partners. Comparisons with other well-regarded development interventions suggest that these effects may place family planning among the most effective interventions to foster human capital formation. The age pattern of results also implies that delayed first births rather than reduced lifetime fertility was primarily responsible for these socio-economic gains. This finding is important because the

\footnotetext{
${ }^{5}$ This study builds on a large literature investigating the broader inter-relationships between fertility and socioeconomic well-being in both developed and developing countries as exemplified by Becker (1960), Becker and Lewis (1973), Willis (1973), Schultz (1974), Easterlin (1978), Easterlin, Pollak, and Wachter (1980), Rosenzweig and Wolpin (1980), Cain (1981), Rosenzweig and Wolpin (1986), Pitt, Rosenzweig, and Gibbons (1993), Gertler and Molyneaux (1994), Foster and Roy (1997), Hotz, Klerman, and Willis (1997), Schultz (1997), Angrist and Evans (1998), Gruber, Levine, and Staiger (1999), Donohue and Levitt (2001), Goldin and Katz (2002), Sinha (2003), Joshi and Schultz (2005), Miller (2005), Bailey (2006), and Pop-Eleches (2006).
} 
development literature generally emphasizes completed lifetime fertility and child quantity more than the lifecycle timing of births.

Six types of evidence address the natural - but seemingly unfounded - concern that the spread of PROFAMILIA's programs was related to secular changes in fertility, socio-economic conditions, or the demand for children. First, through in-person interviews, PROFAMILIA's early leaders explained that they consider program expansion to have been arbitrary and unrelated to demand conditions. Second, raw population census data shows identical completed lifetime fertility among women too old to benefit from family planning (both in level and trend) across municipalities with differentially-timed programs - and staggered fertility declines among younger women that coincide precisely with the introduction of modern contraceptives. Third, municipal characteristics in 1964 (the year before PROFAMILIA was established) are unrelated to the timing of municipal family planning programs. Fourth, implicit program targeting would be evident as program effects among women outside of the biologically-determined ages at which family planning should matter. Statistical analyses demonstrate the absence of any effects at these ages. Fifth, because family planning did not influence women's decision to become mothers, programs targeted to demand conditions among young women would be evident as education or labor force participation effects among women with access to family planning at young ages but never having a child. Analyses confirm the absence of program effects in this control group of women. Finally, all estimates are robust to controlling for fixed and agevarying differences among women across Colombia's municipalities.

This paper is organized in eight sections. The second section provides background on family planning in Latin America and on PROFAMILIA in Colombia. The third describes my data and presents graphical analyses, and the fourth details my empirical strategy. The fifth 
section reports the paper's main results, the sixth presents a variety of validity tests, and the seventh extends the analyses to children's socio-economic outcomes and inequality. The eighth section concludes.

\section{PROFAMILIA and Family Planning in Latin America}

\subsection{The Evolution of Family Planning in Latin America}

The prevailing government philosophy in Latin America during the 1950s and early 1960s was strongly pronatalist, as exemplified by the motto "gobernar es poblar," or "to govern is to populate" (Mundigo 1996). Nation-building required a large body of citizens to create international standing as well as deep consumer markets and a large workforce. Rather than concern about an imminent Malthusian 'population explosion' that would result in mass starvation, it was the alarming incidence of unsafe abortions that first led Latin American governments to take interest in family planning in the mid-1960s. Abortions performed in unsanitary conditions by unqualified personnel were certainly troubling in their own right (they were thought to have been the leading cause of maternal mortality at the time). But they also resulted in large government expenses as women with abortion-related complications sought care en masse from public hospitals (Mundigo 1996).

As Latin American governments began warming up to family planning, they faced daunting opposition to their direct involvement from the Catholic Church and other conservative elements. Consequently, early family planning efforts in Latin America were small, private initiatives funded by international donors and NGOs. ${ }^{6}$ Over time, growing awareness of family

\footnotetext{
${ }^{6}$ The major organizations involved were the International Planned Parenthood Federation (IPPF), the United Nations Population Fund (UNFPA), and the United States Agency for International Development (USAID).
} 
planning as a health input allowed governments to incorporate it into their public health systems.

The prolonged dominance of private family planning services in Colombia was uncommon.

\subsection{PROFAMILIA and the Introduction of Family Planning in Colombia}

In Colombia, the National Association of Medical Schools was the early leader on population issues (Ott 1977). It conducted the first fertility surveys and introduced reproductive health training into the medical curriculum, but intense political pressure forced it not to sponsor the provision of contraceptive services and devices. The national government faced similar political constraints, but importantly, it also chose not to actively oppose private family planning efforts.

The government's tacit acceptance of private initiatives paved the way for the establishment of the private, not-for-profit PROFAMILIA. Its founder, Dr. Fernando Tamayo, was a young obstetrician/gynecologist working in a public hospital in Bogota at the time who also had a small private practice on this side. When he began quietly providing contraceptive devices (primarily IUDs at first) through his practice, the clinic's capacity was quickly overwhelmed by the enormous latent demand for them. Poor women waited in long lines that spilled into the streets, upsetting more affluent patients and causing his practice partners to complain. Rather than turn these women away, he instead sought a new clinic location, resulting in the birth of PROFAMILIA in $1965 .^{7}$

Because of the political quagmire surrounding family planning, PROFAMILIA was the dominant family planning provider in Colombia for many years after its inception. ${ }^{8}$ Its

\footnotetext{
${ }^{7}$ The new location first chosen had to be abandoned when the landlord discovered how the space was being used, reportedly exclaiming: "I don't mind if it is used as a whorehouse, but I will not allow it to be used for family planning!" (Singh 1994)

${ }^{8}$ As late as 1990, PROFAMILIA still provided about $70 \%$ of all family planning services in Colombia.
} 
operations spread to all of Colombia's significant municipalities in subsequent years, growing into a network of 40 municipal program areas over the next decade. Simultaneously, the contraceptive prevalence among married Colombian women of reproductive age rose from a negligible rate in 1964 to $19 \%$ in $1969,34 \%$ in 1976, and 53\% in 1986. Oral contraceptives and IUDs were the most popular devices in the early years. Over time, however, female sterilization has become the most common form of birth control.

PROFAMILIA's international reputation of success was built on the new ways it pioneered to reach women with modern contraceptives under difficult circumstances. Distinguishing features of its philosophy include its focus on the poor and its recruitment of laypeople to provide outreach in their own communities. In municipalities where it operated, PROFAMILIA also supplied vast quantities of contraceptive devices not requiring medical supervision to local drugstores at cost, and it advertised its services by radio. In 1971, PROFAMILIA became the first family planning organization in Latin America to serve rural areas as well.

Figure 1 shows that the demographic transition in Colombia does not resemble the transition in other South American countries. The fertility decline in Colombia during the late 1960s and early 1970s (when PROFAMILIA was expanding) was the most rapid decline on record in South America, and Colombia was not developing more rapidly than its neighbors over this decade. A rough comparison with Venezuela is informative. Venezuela is geographically adjacent to Colombia, shares much of its colonial history, experienced a similar shift from natural resource exports to industrialization in the post-war era, and had comparably high fertility rates during the late 1950 s and early 1960s. However, its privately-funded family planning programs established during the 1960s failed to take root, and its public sector family planning 
activities languished for several decades (Parrado 2000). From 1960-65 to 1985-90, fertility fell by about 3.5 children per woman in Colombia and about 2.75 children per woman in Venezuela - a difference of 0.75 children. This admittedly crude difference-in-difference closely matches the family planning effects that I estimate more formally using within-country variation in PROFAMILIA's location and timing.

\subsection{The Spread of PROFAMILIA's Programs}

Critical to the empirical strategy of this paper is the way that PROFAMILIA's programs spread across Colombia's municipalities. Because the precise timing of PROFAMILIA's programs across municipalities is assumed to be largely exogenous, it is important to investigate any regularity governing the timing and placement of its programs. One of PROFAMILIA's leaders during the 1960s and 1970s, Dr. Gonzalo Echeverry, explained to me that he considers the timing of municipal programs across Colombia to essentially have been arbitrary. After being established in Colombia's two largest cities (Bogota and Medellin), PROFAMILIA spread to many small departmental capitals like Sogamoso, Armero, and Puerto Berrio before reaching other major cities like Cali, Cartagena, and Santa Marta. Program expansion also did not follow any clear geographic pattern. For example, a program began in the coastal city of Barranquilla in 1967, but none was established either in nearby Cartagena or Santa Marta until 1970 and 1972 (respectively).

These observations do not preclude the possibility of implicit program targeting according to demand conditions. However, regressions of program dates on municipal characteristics in 1964 (the year before PROFAMILIA was established) yield no evidence of 
meaningful relationships. ${ }^{9}$ Section 7 presents a wider range of more strenuous validity tests to detect implicit targeting related to changes in demand (not just the level of demand) - including changes in age-specific demand conditions among fertile women. These tests provide robust evidence in support of the identifying assumption.

\section{Data and Graphical Analysis}

\subsection{Data}

Because there is no longitudinal data on Colombian households from the 1960s and 1970s, this study requires that women from different municipalities and birth cohorts be matched to information on the timing and location of PROFAMILIA's programs. In this study, I make extensive use of the Colombian population censuses. The Colombian national statistical agency (Departamento Administrativo Nacional de Estadistica, or DANE) conducted censuses that asked questions about the number of children ever born and the number of children surviving in 1973, 1985, and 1993. To create large samples of women who ranged from not yet fertile to no longer fertile when PROFAMILIA was established in 1965, random samples of approximately one million women born between 1911 and 1955 are used throughout this paper. ${ }^{10}$ I rely primarily on the 1993 census because it allows me to investigate long-run outcomes and to exploit considerable variation in access to family planning among women with complete fertility histories. I also use the 1973 census to investigate the relationship between family planning

\footnotetext{
${ }^{9}$ Characteristics examined in the 1964 population census include municipal population and residents' age, sex, marital status, relationship to the household head, migration history since birth, literacy, employment status, and work history in the past year. Because PROFAMILIA began in Colombia's two largest cities, Bogota and Medellin, program dates are correlated with population size in unavariate regressions $(\mathrm{p}<0.05)$, but this correlation disappears when these two cities are excluded and in multivariate regressions that include the other characteristics. This paper's primary results shown in Tables 2 through 4 are robust to the exclusion of women from Bogota and Medellin. All results not shown are available upon request.

${ }^{10}$ The results are not sensitive to the particular draw used.
} 
access and the timing of first births (which is not explicitly reported). Table 1 shows descriptive statistics from these samples.

Age-specific family planning access that varied by year of birth and place of residence (or birth) was assigned to individual women in these census samples using information from PROFAMILIA's research department on the timing and location of its programs. ${ }^{11}$ Because of uncertainty about when many rural programs began, this paper focuses on municipal program which covered about $40 \%$ of Colombia's population. Following the demography literature, I define women's reproductive ages to be 15-44 and create five-year age intervals (15-19, 20-24, etc.) for all reproductive ages. Dummy variables code each woman's reproductive age interval when a family planning program began in her municipality of residence. ${ }^{12}$

\subsection{Graphical Analysis}

Before turning to more formal analyses, I first present graphical evidence of the relationship between PROFAMILIA's programs and lifetime fertility. This evidence also supports the assumption that program placement and timing was not related to changes in the demand for children. Figure 2 plots average completed fertility among all women ever having children by year of birth in the 1993 population census. ${ }^{13}$ Because cohort-specific fertility is difficult to illustrate separately for each municipality, I divide these municipalities into two groups: those with family planning programs before 1969 ("early" program municipalities), and those with programs in 1969 or later ("late" program municipalities). ${ }^{14}$

\footnotetext{
11 This information is available upon request: ngmiller@stanford.edu.

${ }^{12}$ I choose dummy variables because not all individuals appear to know their precise birth year. Similar results are obtained when age at first access to family planning is coded using women's municipality of birth.

${ }_{13}$ The same patterns are found using all women.

${ }^{14} 1969$ is the population-weighted median year that PROFAMILIA's programs began in these municipalities.
} 
The figure first shows that among women too old to benefit from family planning (those born before 1920, who were 45+ when PROFAMILIA was established in 1965), there were no differences in either fertility levels or trends across areas with differentially-timed programs. Then, among women late in their fertile years when PROFAMILIA was founded (those born between 1920 and 1930, who were 35-45 in 1965), fertility in the early program municipalities pulls slightly below fertility in the late ones. This divergence between early and late areas becomes much more pronounced among women born in 1930 or later (who were 35 or younger in 1965). Among women just becoming fertile when PROFAMILIA was established (those born in 1950 or just before 1950), the amount of time it took fertility in late program municipalities to catch up to fertility in the early ones (the horizontal distance between the early and late program series) is three to four years. Strikingly, this is exactly the difference in time between the average early group program and the average late group program. The two fertility series then re-converge among younger women having access to family planning at all fertile ages regardless of where they live (women born around 1965 or later). ${ }^{15}$ This convergence should not be complete because a few municipalities in the late group did not have programs until the 1980s. The younger birth cohorts also reflect intergenerational program effects because they include the daughters of women who had varying access to modern contraceptives.

To see the age and timing of program effects more clearly, Figure 3 shows average completed fertility by age at first access to family planning. After removing cohort effects, age when programs were introduced is negatively related to completed lifetime fertility. ${ }^{16}$ More precisely, this association is present at fertile ages from the mid-teens through the mid-30s and

\footnotetext{
${ }^{15}$ Women born in the early 1950s or later were still fertile at the time of the 1993 census, so their fertility should not be interpreted as completed lifetime fertility.

${ }^{16}$ Figure 3 was produced by regressing lifetime fertility on birth cohort dummy variables and then plotting the residuals by age at first access to family planning (and scaling them by lifetime fertility among women age 50-54 in 1965).
} 
absent at infertile ages. Figure 3 shows that access to family planning at all fertile ages is associated with a completed lifetime fertility reduction of about 0.75 children controlling only for cohort effects. This reduction very closely matches statistical estimates that I present later.

Figures 2 and 3 show clear evidence that PROFAMILIA's programs were associated with lower fertility rates. They also support the assumption that program placement and timing was not related to the demand for children. Pre-program levels correlated with program timing would be evident in Figure 2 among women born before 1920, and pre-program trends correlated with program timing would be evident in Figure 3 among women first exposed to family planning at infertile ages.

\section{Empirical Strategy}

\subsection{Fertility}

This paper presents reduced-form estimates of family planning's consequences by exploiting the distinct timing, geographic pattern, and age-specific nature of PROFAMILIA's programs. Unobserved individual characteristics presumably influence the use of contraceptive services and devices, so program effects identified by variation in utilization would be biased. For this reason, the effects of family planning access are estimated rather than the effects of contraceptive use.

A simple approach would be to compare the fertility of women who are the same age but live in different municipalities and therefore differ in access to family planning. However, municipalities with differentially-timed programs could vary in fertility for reasons unrelated to family planning (although Figures 2 and 3 suggest that this was not the case). An alternative 
would be to compare the fertility of different aged women in the same municipality. In this case, program effects could not be disentangled from cohort effects.

To circumvent these difficulties, I combine the two approaches, using only joint variation in the timing and location of PROFAMILIA's programs to identify their age-specific effects. In doing so, I assume that the combination of variation in contraceptive access across municipalities and over time is exogenous. This implies that women the same age in municipalities with differentially-timed programs would have experienced the same changes in fertility over time in the absence of family planning. It also implies that after controlling for age, fertility differences between younger and older women in the same municipality are attributable only to family planning. Section 7 devotes considerable attention to evaluating the validity of the identifying assumption.

I focus on two distinct lifetime fertility choices that contraceptive access could affected: whether or not to have children and how many births to have conditional on having any. ${ }^{17} \mathrm{~A}$ two-part empirical model allows family planning effects to differ for these two choices. This approach is also one way of handling censoring at zero in the distribution of births. For individual women $i$, birth years $y$, municipalities $m$, and reproductive age intervals $a$, I begin by estimating:

$$
\operatorname{Pr}\left(b_{i y m}=1\right)=\Phi\left[\alpha+\sum_{a} \beta_{a} r_{a y m}+\delta_{y}+\varepsilon_{i y m}\right]
$$

and conditional on ever giving birth $\left(b_{i y m}=1\right)$,

$$
\ln \left(n_{i y m}\right)=\omega+\sum_{a} \gamma_{a} r_{a y m}+\delta_{y}+\xi_{i y m}
$$

\footnotetext{
${ }^{17}$ The former provides a means of investigating the timing of first births, too, as discussed in Section 6.1.
} 
In these simple specifications, the choices of ever having a child $(b)$ and the number of births $(n)$ are assumed to depend on a constant, the reproductive age interval $(r)$ in which PROFAMILIA's programs first became available to woman $i(15-19,20-24, \ldots, 40-44)$, and birth year dummies $\left(\delta_{y}\right) ; \Phi$ represents the standard normal cumulative density function. By controlling only for year of birth, these equations estimate program effects as if the location and timing of PROFAMILIA's programs were randomized. The $\beta$ s and $\gamma$ s are estimates of family planning effects for women first exposed to family planning in each reproductive age interval $(15-19,20$ $24, \ldots, 40-44) .{ }^{18}$ The interpretation of the $\gamma$ s would be more complicated if I found that family planning affected the decision to have children (if the $\beta \mathrm{s} \neq 0$ ), but as shown in section 6 , this is not the case. I next re-estimate these equations including additional independent variables:

$$
\operatorname{Pr}\left(b_{i y m}=1\right)=\Phi\left[\alpha+\sum_{a} \beta_{a r a y m}+\delta_{m}+\delta_{y}+\delta_{m} \times y+\lambda g_{i y m}+\mathcal{E}_{i y m}\right],
$$

and conditional on ever giving birth $\left(b_{i y m}=1\right)$,

$$
\ln \left(n_{i y m}\right)=\omega+\sum_{a} \gamma_{a r a y m}+\delta_{m}+\delta_{y}+\delta_{m} \times y+\pi g_{i y m}+\xi_{i y m} .
$$

Equations (3) and (4) also include municipality dummy variables $\left(\delta_{m}\right)$, municipality-specific linear time trends $\left(\delta_{m} \times y\right)$, and a dummy variables indicating whether or not a woman has ever moved $(g)$. If joint variation in the location and timing of PROFAMILIA's programs was truly exogenous, the age-specific program effect estimates from equations 3 and 4 should not be different than those obtained from 1 and 2.

\footnotetext{
${ }^{18}$ A dummy variable is included for the age range 10-14 as well, and its coefficient estimate is indistinguishable from the one on age range 15-19. I also include a dummy variable for age range 45-49, as discussed in Section 7 under Validity Tests. The omitted age-range is 50-54.
} 
The logarithmic transformation of births in equations 2 and 4 is reasonable given its right-skewed distribution (conditional on any births). ${ }^{19}$ However, count data models also fit the distribution of births well. In particular, negative binomial models provide an attractive alternative and are more appropriate than poisson models in instances of unequal mean and variance given their flexible dispersion parameter (Cameron and Trivedi 1998). ${ }^{20}$ For this reason, both log-linear program effect estimates and negative binomial estimates are presented side-by-side in the Results section.

\subsection{Socio-Economic Status}

To estimate the consequences of contraceptive access for women's socio-economic status, I employ reduced-form approaches as shown in equations 3 and 4. A variety of socioeconomic outcomes are used as dependent variables: women's years of educational attainment, dichotomous indicators for formal sector employment and "white collar" occupations (conditional on working in the formal sector), cohabitation, and self-reported infant/child mortality. ${ }^{21}$ I rely exclusively on a reduced-form approach because family planning may affect socio-economic outcomes through pathways other than completed lifetime fertility. For example, I present evidence in Section 6.1 that family planning influenced the timing of births as

\footnotetext{
${ }^{19}$ Retransformation back to the raw scale is problematic when the error term is heteroskedastic across treatment groups (Manning 1998, Buntin and Zaslavsky 2004). However, regressions of log squared residuals on age-specific program exposure suggest that this is not problematic in my case.

${ }^{20}$ In the terminology of Cameron and Trivedi (1998), I specifically use a NB2 model where the dependent variable $y$ is assumed to have mean $\mu=\exp (\mathrm{X} \beta)$ and variance $\mu+\alpha \mu^{2}$ (where $\mathrm{X}$ is a vector of independent variables): $f(y \mid \mu, \alpha)=\frac{\Gamma\left(y+\alpha^{-1}\right)}{\Gamma\left(y^{y+1}\right) \Gamma\left(\alpha^{-1}\right)}\left(\frac{\alpha^{-1}}{\left(\alpha^{-1}+\mu\right)}\right)^{\alpha^{-1}}\left(\frac{\mu}{\alpha^{-1}+\mu}\right)^{y}$. Estimates of the dispersion parameter $\alpha$ range from 0.04 to 0.10 and are statistically different from zero at conventional levels, suggesting the presence of modest overdispersion.

${ }^{21}$ Formal sector employment is defined as working for an establishment with three or more employees. "White collar" occupations were coded from a list of occupations to distinguish clerical and office-based jobs from manual labor. Cohabitation is defined here as either marriage or an extra-marital "free-union." Infant/child mortality is defined as the difference between a woman's reported number of lifetime births and reported number of surviving children divided by her reported number of lifetime births.
} 
well as the number of births. The exclusion restriction required to instrument for completed lifetime fertility using family planning access is therefore probably not met.

\section{Results}

\subsection{Fertility Results}

Tables 2 and 3 present estimates of how age-specific access to family planning affected women's fertility choices. Dependent variables are shown at the top of the columns, and cells within columns show the association between first having access to family planning within a given age-range (15-19, 20-24, etc.) and the corresponding fertility outcome. The first column for each dependent variable generally provides program effect estimates conditional only on cohort dummy variables ("Cohort Only"). The second column for each dependent variable generally shows estimates conditional on the full set of covariates ("All Covariates"). These

specifications include municipality fixed-effects and municipality-specific linear trends exactly as shown in equations 3 and 4 . I emphasize the results obtained using the larger set of covariates but highlight that the estimates are robust to controlling for fixed and time-varying differences across municipalities. The statistical equivalence of estimates obtained using different sets of covariates supports the assumption that the spread of family planning was largely exogenous.

The first and second columns of Table 2 show log-linear program effect estimates for lifetime fertility among women ever having a child (the second part of the two-part model as shown in equations 2 and 4). Because the dependent variable is in logarithmic form, coefficient estimates can roughly be interpreted as percent changes in lifetime births associated with first having access to family planning in each age interval. In general, gaining access to PROFAMILIA's programs was negatively associated with lifetime fertility for women in their 
late teens through their early thirties. Relative to women without family planning access while fertile, lifetime access was associated with about $13 \%$ fewer births (the estimate for "Family Planning Access 15-19"). From a base of six births, this reduction is equivalent to about threequarters of a child. Lifetime fertility effects are progressively smaller for women who were older when modern contraceptives became available. Women first exposed to family planning at ages 30-34 had about $4 \%$ fewer children, and no program effects are evident among women first exposed at age 35 or beyond.

The third and fourth columns of Table 2 show comparable negative binomial estimates. Although somewhat smaller than the log-linear estimates in the first two columns, these estimates tell the same story. ${ }^{22}$ Women ages $15-19$ when family planning programs began gave birth to about $7 \%$ fewer children in their lifetime (or about 0.4 children). Program effects are again present among women first exposed to family planning at ages up to their early thirties.

The first two columns of Table 3 show program effect estimates from the first part of the two-part model (equations 1 and 3) for women's decision ever to have children. Among women with completed fertility, they show no evidence that access to family planning at any age is associated with the choice to become a mother. These point estimates that are very near zero are precisely estimated. Combining estimates from both parts of the model, PROFAMILIA's programs explain between $9 \%$ and $12 \%$ of the fertility decline in program municipalities between 1964 and 1993.

Although the Colombian population censuses do not report the year of women's births, the result that family planning did not influence the decision ever to have children provides a way of investigating program effects on the timing of first births. The 1973 census was

\footnotetext{
${ }^{22}$ The negative binomial model produces a slightly larger log-likelihood value than the maximum likelihood equivalent of the log-linear OLS model.
} 
conducted shortly after PROFAMILIA established programs in many areas, and young women exposed to programs in these areas still had many fertile years ahead of them. Program effects on whether or not young women had children at the time of the 1973 census can therefore be interpreted as effects on the timing of first births. The third column of Table 3 presents estimates from the 1973 census comparable to those from the 1993 census shown in the second column. The major difference is that women gaining access to family planning in their late teens were about $3 \%$ less likely to be mothers in 1973. This result suggests that PROFAMILIA's programs allowed women ages 15-19 to postpone their first birth. Because this estimate only captures first births postponed from before until after 1973 census was conducted, the magnitude of delayed first births is presumably much larger.

\subsection{Socio-Economic Results for Women}

Table 4 shows results for women's socio-economic status among women ever having children (and whose fertility changed under family planning). Each column shows estimates for a different socio-economic outcome with the dependent variable at the top of the column. The first column presents program effect estimates for years of education. Relative to women without access to family planning while fertile, women ages 15 to 19 when PROFAMILIA established a program completed 0.14 more years of schooling. From a base of slightly less than 7 years of schooling, this is an increase of more than $2 \%$. There is also weaker evidence that women first exposed to family planning in their early twenties completed more schooling as well. In general, these are large effects that could be due to the postponement of first births, reductions in completed lifetime fertility, or both. The absence of meaningful effects among 
fertile women just beyond school age provides additional support for the assumption that family planning program placement was unrelated to the demand for children. ${ }^{23}$

The second column of Table 4 shows that family planning access at young ages was associated with greater probabilities of working in the formal sector in 1993. Women first exposed to family planning at ages $15-19$ and 20-24 were 3 percentage points more likely to be working. These gains represent increases of $5 \%$ in the probability of formal sector employment. However, because the censuses only report employment in the formal sector, it is possible that these estimates also capture occupational choice effects. Shifts from informal to formal sector work would be combined with increases in employment. The third column shows no evidence that conditional on formal sector employment, women were not more likely to have "white collar" or professional occupations because of family planning access.

The fourth column of Table 4 shows that access to family planning under age 25 reduced the probability that women were cohabitating in 1993 (either married or in an extra-marital "freeunion”). Women 15-19 and 20-24 when PROFAMILIA established a program were about 2 percentage points less likely to be cohabitating in 1993, a reduction of about $3 \%$. The welfare consequences of cohabitation are more ambiguous than for other socio-economic outcomes considered in this paper; even the direction of the effect may depend on the circumstances. For example, there may be gains from specialization in household production (Becker 1981, Lundberg, Pollak, and Wales 1997, Pollak 2005), but women with little bargaining power within households (and their children) may do better by living independently as women's labor market opportunities improve.

\footnotetext{
${ }^{23}$ Five-year undergraduate degrees are generally terminal, even among the elite. Some limited masters-level training also occurs.
} 
Finally, the last column shows no evidence that family planning affected self-reported infant and child mortality. The point estimates corresponding to first being exposed to family planning in each age interval are very close to zero, and they are precisely estimated. However, measurement error is likely more problematic for self-reported infant and child mortality. These inaccuracies could be correlated with family planning access, or they could simply result classical measurement error; the sign of the potential bias is unclear. Changes in the composition of births could also be relevant. Because first-born children are generally more likely to die, lower age-specific infant and child mortality rates could be offset as first births grow as a share of total births (Bongaarts 1987). Nevertheless, the absence of detectable family planning effects stands in stark contrast to the common belief that the number and timing of births are important determinants of infant mortality (Wolpin 1997).

It is noteworthy that all statistically meaningful socio-economic effects shown in Table 4 occur among women who first had access to modern contraceptives at young ages. Although Table 2 shows that gaining access to family planning was associated with lower completed lifetime fertility among women up to age 35 , Table 4 reports essentially no socio-economic program effects past age 24 . The close correspondence between ages at which first births were postponed and ages at which socio-economic benefits occurred suggests that the timing of first births may be a more important determinant of socio-economic outcomes than completed lifetime fertility.

\section{Validity Tests}

This section examines the identifying assumption of exogenous joint program placement and timing in detail and then investigates other possible concerns about the confounding 
influence of migration, selective attrition due to differential mortality, incomplete fertility histories, and contamination.

The graphical evidence in Section 4 suggests that joint variation in program location and timing is exogenous, but this assumption can be evaluated statistically, too. One approach is to test for program effects on any outcome among women outside of the biologically-determined ages at which they should benefit from family planning (ages $45-49$, for example). This is similar to testing for relative changes in fertility or markers related to the demand for children (such as education and labor force participation) just before programs were established (as would be possible in panel data). Effects at these ages would suggest that the estimates presented in Tables 2 through 4 mistakenly capture either pre-existing trends in fertility or socio-economic status or mean reversion. Tables 2 through 4 show the absence of program effects at ages 45-49 for all fertility and socio-economic outcomes available in the population censuses. Table 5 shows results obtained by re-estimated equations 3 and 4 for fertility and socio-economic outcomes using the entire census population of women ages 45-49 and 50-54 when family planning programs began. Doing so follows the logic of estimating program effects for women ages 45-49 in Tables 2 and 4 but has even greater power to detect meaningful differences from zero. For educational attainment, I conduct this test for women just past schooling age (25-29) relative to women five years older (30-34). Table 5 shows no evidence of program effects on any outcome at these ages. Comparisons among successively older age groups of women (not shown) also yield precise estimates that are indistinguishable from zero.

Another important way to test the identifying assumption is to test for program effects at all ages among women who never had children. Because family planning did not affect women's decisions to become mothers, women the same age and in the same municipalities but who never 
gave birth form a reasonable control group for women with children. Importantly, this test allows me to detect confounding secular socio-economic trends that are specific to any cohort by municipality cell of women. The additional benefit of this test over the ones presented in the previous paragraph is that it can detect program targeting specific to changing demand conditions among young women (the ones most likely to benefit from family planning). Table 6 shows age-specific program effects obtained by re-estimating equations 3 and 4 for socioeconomic outcomes among women who never had a child - there is no evidence of any program effect at any age on any socio-economic outcome among these women. ${ }^{24}$ Taken together, the validity tests presented thus far imply that if there were any confounding force responsible for this paper's major findings, it must have varied in a very specific way - across municipalities and over time in the same pattern as PROFAMILIA's programs, only affecting women at biologically plausible ages within each municipality, and only affecting women who ever became mothers. This possibility seems quite unlikely. In particular, the tendency of programs to have been established somewhat earlier in larger municipalities does not appear to reflect differentially-changing demand conditions.

In addition to the validity of the identifying assumption, there are also other potential objections that should be addressed. One is the possibility of selection due to unobserved migration. By influencing socio-economic conditions, the establishment of family planning programs might have non-randomly attracted women from surrounding areas. There was in fact unprecedented migration from rural to urban areas during the period studied; about $15 \%$ of individuals in the 1993 census had moved during the last five years, and nearly $40 \%$ had moved in their lifetime (although not necessarily to a different municipality). Because family planning

\footnotetext{
${ }^{24}$ About $15 \%$ of women in the sample never had a child. Larger draws of women never giving birth confirm that the absence of statistical significance in Table 6 is not due to sample size.
} 
access was governed by age and municipality of residence, unobserved migration could possibly bias the estimates presented. However, several pieces of evidence suggest that this paper's major findings are not due to selection acting through migration. First, the estimates shown in Tables 2 through 4 are not sensitive to conditioning on migration history (ever having moved). Second, although movers and never-movers may differ in unobserved ways, Table 1 suggests that their observable characteristics are very similar. Third, Table 7 shows that re-estimating equations 3 and 4 in a restricted sample of women who have never moved yields the same pattern of results as shown in Tables 2 through 4 . Finally, coding family planning access according to municipality of birth rather than municipality of residence (not shown) also yields the same general pattern of results.

Another concern might be the possibility of selective attrition. If family planning altered women's survival rates (by resulting in fewer unsafe abortions, for example), it would also alter the composition of women across municipalities in the censuses, biasing program effect estimates. Colombia's low-quality vital statistics from the 1960s and 1970s make it difficult to investigate this possibility directly. However, the direction of any selective attrition bias is most likely downward. Poor women are disproportionately likely to seek unsafe abortions. Because abortions and modern contraceptives are presumably substitutes, poor women would therefore have higher survival rates in municipalities with earlier family planning programs. So poor women would comprise a larger share of all women in municipalities with earlier programs, and poor women have higher fertility rates, earlier first births, and worse socio-economic indicators on average. Any selective attrition would therefore most likely result in downward bias.

Finally, although the municipalities examined by this paper are not geographically contiguous, a potential concern might be that PROFAMILIA's programs benefited areas other 
than the municipalities in which they were based. This possibility is unlikely. Colombia is environmentally diverse, and most of its major population centers are separated by hostile mountainous stretches of the Andes. Colombians will readily attest that geographic distance and travel time in much of the country are virtually unrelated to each other. It is therefore difficult to imagine that modern contraceptives reached areas other than those immediately served by PROFAMILIA's programs. In the unlikely event that they did, however, the resulting bias would be downward.

\section{Extensions}

\subsection{Socio-Economic Results for Children}

If family planning affects the number and timing of women's births, it may have very important consequences for investments that parents make in their children, too. Because the Colombian population censuses do not completely specify intra-household relationships, however, I am unable to match many children to their biological mothers and therefore cannot directly estimate program effects on the children of women with differential family planning access. Instead, I construct "statistical mothers" for children using the mean characteristics of women who ever had children and were fertile in each child's municipality and year of birth. I match these characteristics to children and assign age-specific family planning access according to statistical mother's age and municipality of residence. This statistical mother approach reduces the variation in program exposure that I am able to exploit considerably; the resulting estimates should only be interpreted as suggestive. ${ }^{25}$

\footnotetext{
${ }^{25}$ This approach also requires that family planning access be unrelated to the distribution of maternal characteristics at the age by municipality level. I find no evidence of any relationship.
} 
The relationship between women's access to family planning and child outcomes is estimated by the general equation:

$$
c_{i y m}=\alpha+\sum_{a} \beta_{a S a y m}+\delta_{m}+\delta_{y}+\delta_{m} \times y+\pi x_{y m}+\lambda g_{y m}+\varepsilon_{i y m}
$$

Child outcomes $(c)$ include whether or not a child is attending school, years of educational attainment, and whether or not a child is working in the formal sector. The age interval in which family planning first became available to statistical mothers $(s)$ is coded as before, and statistical mother age $(x)$ and probability of having migrated in her lifetime $(g)$ are controlled for as well. To investigate intra-household differences in the distribution of family planning benefits by children's gender, I estimate equation 5 for boys and girls both separately and together in a pooled sample. Analyses are restricted to children ages 10-14 in 1993 because it is not possible to condition on a girl's own age-specific access to family planning when estimating the effect of statistical mothers' family planning access (both are a function of a child's age and municipality).

Table 8 shows estimates for children's socio-economic status obtained from equation 5. Dependent variables are shown at the top of each column; rows correspond to different samples (boys and girls together, boys only, and girls only). Each cell presents results for statistical mother family planning access at all fertile ages (beginning at ages 15-19) relative to no access at any fertile age. Estimates in the first row suggest that the children of women with lifetime access to family planning were two percentage points more likely to be attending school, had received 0.08 more years of education, and were less likely to be working in the formal sector. Broken down by gender, the second and third rows together suggest that boys enjoyed these benefits disproportionately more than girls. Girls possibly gained some additional schooling and were 
less likely to become teenage mothers, but boys enjoyed nearly all of the gains in school attendance and reductions in child labor.

On the whole, Table 8 provides suggestive evidence that family planning played an important role in reducing the intergenerational transmission of poverty. However, there were striking gender disparities in distribution of these benefits. These disparities are consistent with the literature on gender bias in household resource allocation (Rosenzweig and Schultz 1982, Sen 1992, Thomas 1994, Duflo 2003). They may also reflect changes in the sex composition of children under family planning. If modern contraceptives allowed parents to adhere more closely to fertility rules based on male preference, girls' outcomes may be relatively worse because they would tend to be in larger families. ${ }^{26}$

\subsection{Family Planning and Inequality}

In addition to improving average levels of well-being, contraceptive access may have important consequences for socio-economic inequality. Because better educated women have larger opportunity costs of time and stronger incentives to limit their fertility (Chen and Kremer 2002), it could increase inequality. There may also be diminishing returns to averted births, so fertility reductions at lower levels might produce larger benefits. Alternatively, less educated women may face larger costs of fertility control in the absence of modern contraceptives (if they are less empowered, for example). In this case, they might benefit more from family planning, and socio-economic inequality would fall.

\footnotetext{
${ }^{26}$ There is evidence of such rules in other settings (Park 1983, Ahn 1991) as well as anecdotal evidence from Colombia: “... The total number of children was related to the order in which sons and daughters were born. Couples continued to have children until they had enough sons to balance the financial demands of raising their daughters" (Ortiz 1999).
} 
Plausibly exogenous variation in education or socio-economic status is necessary to test this hypothesis using individual-level data. Instead, I exploit the staggered introduction of PROFAMILIA's programs by regressing the standard deviation (and log standard deviation) of education at the municipal level in 1993 on the number of years that family planning was available, controlling for municipal characteristics in $1973 .{ }^{27}$ The results (not shown) provide evidence of statistically meaningful reductions in educational inequality under family planning (standard deviation reductions of 0.01 years of schooling per year of family planning availability, or about $0.3 \%$ per year). For 25 years of program exposure, this translates into standard deviations that are smaller by about 0.25 years (or $7.5 \%$ ). These results are consistent with family planning having reduced socio-economic inequality in Colombia. There is independent evidence that income inequality declined substantially in Colombia during the 1970s as PROFAMILIA was scaling-up its programs (Birchenall 2001).

\subsection{Program Costs}

In addition to the size of family planning's benefits, a key issue is how much it costs to produce them. A formal cost-benefit analysis of PROFAMILIA's programs is not generally possible because many of its benefits cannot be directly estimated and valued. Women's empowerment is a good example of this. Crude program cost and cost-effectiveness calculations are feasible, however. Arguably the strongest criticism of the Matlab experiment is its unrealistic program expenses and its large cost-effectiveness ratio. The Matlab family planning 'treatment' cost about $10 \%$ of per capita GDP per fertile woman and about $120 \%$ of per capita GDP per averted birth (Pritchett 1994). PROFAMILIA's programs were dramatically less

\footnotetext{
${ }^{27}$ These are mean age, share female, share employed in the formal sector, share cohabitating, share ever moved, and share moved in the last 5 years in 1973. Although not possible, it would be preferable to control for municipal characteristics in 1964.
} 
expensive relative to national income (Seltzer and Gomez 1998). Specifically, program costs were about $0.1 \%$ of per capita GDP per fertile woman in program municipalities (about 1/100th of the Matlab costs relative to income) and about $0.25 \%$ of per capita GDP per birth averted (about 1/500th of the Matlab costs relative to income). These rough calculations suggest that family planning can be successful for considerably less than in Matlab.

\subsection{Comparisons with Other Interventions}

Given debate over the importance of family planning in reducing poverty and promoting development, informal comparisons with other development interventions are informative. The results in Section 6.2 demonstrate that educational gains are a clear benefit of family planning. Improving education is a cornerstone of efforts to alleviate poverty, increase productivity, and promote economic growth in poor countries (Glewwe 2002). Rough comparisons with other interventions that specifically target education therefore help to put the importance of family planning into context.

One well-documented program provided school vouchers to subsidize private secondary school tuition in Colombia (where private education is thought to be higher-quality) (Angrist, Bloom, King, and Kremer 2002). In the short-run, vouchers raised educational attainment by 0.1 years of schooling, or about $1.5 \%$. Another initiative was Indonesia's massive school construction program during the 1970s (Duflo 2001). The construction of over 60,000 schools during a five-year period increased schooling by about 0.15 years on average, or roughly $2 \%$. A third intervention was the introduction of compulsory school attendance and child labor laws in the early 20th Century United States (Lleras-Muney 2002). Taken together, these laws increased educational attainment by $5 \%$, or around half a year. Finally, a study of school resources and 
education among blacks under South Africa's apartheid-era government suggests that reducing class size by one-quarter would increase schooling by half a year, or about 6\% (Case and Deaton 1999). PROFAMILIA's programs increased women's education by an amount roughly equivalent to some these initiatives that specifically targeted education (about 0.14 years, or more than 2\%). In other words, its education benefits alone place it among some of the most highly-regarded development initiatives.

\section{Conclusion}

In light of the ongoing debate about family planning's ability to reduce fertility in developing countries, this paper suggests that neither side is exactly right. However, it sides more closely with the view that other forces (originating either on the supply- or demand-side) are more potent. PROFAMILIA's programs reduced women's completed lifetime fertility by roughly half a child, but they explain only $9 \%$ to $12 \%$ of the fertility decline in program municipalities between 1964 and 1993 as Colombia underwent its demographic transition.

Despite its modest role in reducing lifetime fertility, this paper also demonstrates that the ability of family planning to fight poverty cannot easily be dismissed. Colombian women with access to modern contraceptives at young ages experienced substantial socio-economic gains. A formal cost-benefit analysis of PROFAMILIA's programs would be difficult because many of its benefits are hard to value. However, the gains in education alone attributable to family planning place it among some of the best-regarded education interventions. Given that 350 million couples worldwide presently lack access to family planning services (United Nations Population Fund, 2004), family planning may deserve more attention in dialogue surrounding the Millennium Development Goals and poverty relief in general. 
The age pattern of results suggests that family planning most likely generated socioeconomic benefits by allowing young women to postpone their first birth. This finding implies that the development literature's focus on completed lifetime fertility and child quantity overlooks a critical dimension of fertility emphasized by wealthy country studies - the lifecycle timing of births (and first births in particular) (Ribar 1999, Goldin and Katz 2002, Bailey 2006). It also suggests that Latin America's contemporary increases in teenage motherhood may have more detrimental consequences than is presently recognized (Florez and Nuñez 2002).

Finally, this paper's major findings imply that fertility control can be quite costly in the absence of modern contraceptives. Significant dimensions of these costs may include forgoing desired sexual activity and women with relatively little bargaining power negotiating sexual behavior and fertility with men. Because the costs of fertility control in developing countries are poorly understood, this is an important topic for further research. Policies that aim to help women achieve their desired level of fertility or to improve economic and social conditions generally may do well to emphasize reducing the costs of fertility control beyond what family planning achieves. 


\section{References}

Ahn, N. "Measuring the Value of Children by Sex and Age Using a Life-Cycle Model of Fertility," Yale University Economic Growth Center Discussion Paper \#648 (1991).

Angrist, J., Bettinger, E., Bloom, E., King, E., and M. Kremer. "Vouchers for Private Schooling in Colombia: Evidence from a Randomized Natural Experiment," American Economic Review 92 (2002), 1535-1558.

Angrist, J. and W. Evans. "Children and Their Parents' Labor Supply: Evidence from Exogenous Variation in Family Size," American Economic Review 88 (1998), 450-477.

Bailey, M.J. "More Power to the Pill: The Impact of Contraceptive Freedom on Women's Lifecycle Labor Supply," Quarterly Journal of Economics 121(1) (2006), forthcoming.

Becker, G.S. "An Economic Analysis of Fertility," in Demographic and Economic Change in Developed Countries. Princeton, N.J.: Princeton University Press, 1960.

Becker, G.S. A Treatise on the Family. Cambridge, MA: Harvard University Press, 1981.

Becker, G.S., H. Lewis. "On the Interaction Between the Quantity and Quality of Children," Journal of Political Economy 81(2.2) (1973), S279-S288.

Becker, G.S., Murphy, K.M., and R. Tamura. "Human Capital, Fertility and Economic Growth," Journal of Political Economy 98(5.2) (1990), S12-S37.

Birchenall, J. "Income Distribution, Human Capital and Economic Growth in Colombia," Journal of Development Economics 66 (2001), 271-287.

Bongaarts, J. "Does Family Planning Reduce Infant Mortality Rates?” Population and Development Review 13(2) (1987), 323-334.

Bongaarts, J. "The Impact of Population Policies: Comment," Population and Development Review 20 (1994), 616-620.

Buntin, M.B. and A.M. Zaslavsky. "Too Much Ado about Two-Part Models and Transformation? Comparing Methods of Modeling Medicare Expenditures," Journal of Health Economics 23 (2004), 525-542.

Cain, M. "Risk and Insurance: Perspectives on Fertility and Agrarian Change in India and Bangladesh," Population and Development Review 7 (1981), 435-474.

Cameron, A.C. and P.K. Trivedi. Regression Analysis of Count Data. Cambridge: Cambridge University Press, 1998.

Caldwell, J.C. Theory of Fertility Decline. London: Academic Press, 1982. 
Case, A. and A. Deaton. "Large Cash Transfers to the Elderly in South Africa," Economic Journal 108 (1998), 1330-1361.

Case, A. and A. Deaton. "School Inputs and Educational Outcomes in South Africa," Quarterly Journal of Economics 114(3) (1999), 1047-1084.

Chen, D. and M. Kremer. "Income Distribution Dynamics with Endogenous Fertility," Journal of Economic Growth 7(3) (2002), 227-258.

Donohue, J.J. and S.D. Levitt. "The Impact of Legalized Abortion on Crime," Quarterly Journal of Economics 116(2) (2001), 379-420.

Duflo, E. "Schooling and Labor Market Consequences of School Construction in Indonesia: Evidence from an Unusual Policy Experiment," American Economic Review 91(4) (2001), 795813.

Duflo, E. "Grandmothers and Granddaughters: Old Age Pension and Intra-Household Allocation in South Africa," World Bank Economic Review 17(1) (2003), 1-25.

Easterlin, R.A. "The Economics and Sociology of Fertility: A Synthesis," in C. Tilley (ed.), Historical Studies of Changing Fertility. Princeton, NJ: Princeton University Press, 1978.

Easterlin, R.A., Pollak, R.A., and M.C. Wachter. "Toward a More General Economic Model of Fertility Determination: Endogenous Preferences and Natural Fertility," in R.A. Easterlin (ed.), Population and Economic Change in Developing Countries. Chicago, IL: The University of Chicago Press, 1980.

Ehrlich, P. and A. Ehrlich. The Population Explosion. New York: Simon and Schuster, 1990.

Ehrlich, P. and J. Holdren. "Impact of Population Growth," Science 171 (1971), 1212-1217.

Florez, C.E. and J. Nuñez. "Teenage Childbearing in Latin American Countries," Universidad de Los Andes Centro de Estudios Sobre Desarrollo Economico Working Paper 2002-01 (2002).

Foster, A.D. and N. Roy. "The Dynamics of Education and Fertility: Evidence from a Family Planning Experiment," Mimeo, Brown University, 1997.

Gertler, P.J. and J.W. Molyneaux. "How Economic Development and Family Planning Programs Contributed to Reduce Indonesian Fertility," Demography 31(1) (1994), 33-63.

Gertler, P.J., Shah, M., and S. Bertozzi. "Sex Sells, But Risky Sex Sells for More,” Mimeo, University of California Berkeley, 2003.

Glewwe, P. "Schools and Skills in Developing Countries: Education Policies and Socioeconomic Outcomes," Journal of Economic Literature XL (2002), 436-482. 
Goldin, C., and L. Katz. "The Power of the Pill: Oral Contraceptives and Women's Career and Marriage Decisions," Journal of Political Economy 110(4) (2002), 730-770.

Gruber, J., Levine, P.B., and D. Staiger. “Abortion Legalization and Child Living Circumstances: Who is the 'Marginal Child?'," Quarterly Journal of Economics 114(1) (1999), 263-291.

Guzman, J.M., Singh, S., Rodriguez, G., and E.A. Pantelides. The Fertility Transition in Latin America. New York: Oxford University Press, 1996.

Hotz, V.J., Klerman, J.A., and R.J. Willis. "The Economics of Fertility in Developed Countries," in Mark Rosenzweig and Oded Stark (eds.), Handbook of Population and Family Economics Volume 1A. Oxford: Elsevier Science, 1997.

Joshi, S. and T.P. Schultz. "Family Planning as an Investment in Female Human Capital: Evaluating the Long Term Consequences in Matlab, Bangladesh," Mimeo, Yale University, 2005.

Koenig, M.A., Phillips, J.F., Simmons, R.S., and M.A. Kahn. "Contraceptive Use in Matlab, Bangladesh in 1990: Levels, Trends, and Explanations," Studies in Family Planning 23(6) (1992), 352-364.

Lleras-Muney, A. "Were Compulsory Attendance and Child Labor Laws Effective? An Analysis from 1915 to 1939," Journal of Law and Economics 45(2) (2002), 401-435.

Lundberg, S., Pollak, R., and T. Wales. "Do Husbands and Wives Pool Their Resources? Evidence from the U.K. Child Benefit," Journal of Human Resources 32 (1997), 463-480.

Manning, W.G. "The Logged Dependent Variable, Heteroscedasticity, and the Retransformation Problem," Journal of Health Economics 17 (1998), 283-295.

Miller, A.R. “The Effects of Motherhood Timing on Career Path,” Mimeo, University of Virginia, 2005.

Mundigo, A.I. "The Role of Family Planning Programmes in the Fertility Transition of Latin America," in Guzman, J.M., Singh, S., Rodriguez, G., and E.A. Pantelides (eds.), The Fertility Transition in Latin America. New York: Oxford University Press, 1996.

Oritz, S. Harvesting Coffee, Bargaining Wages. Ann Arbor: University of Michigan Press, 1999.

Ott, E.R. "Population Policy Formation in Colombia: The Role of ASCOFAME," Studies in Family Planning 8(1) (1977), 2-10. 
Park, C.B. "Preference for Sons, Family Size and Sex Ratio: An Empirical Study in Korea," Demography 20 (1983), 333-352.

Parrado, E.A. "Social Change, Population Policies, and Fertility Decline in Colombia and Venezuela," Population Research and Policy Review 19 (2000), 421-457.

Phillips, J.F., Simmons, R.S., Koenig, M.A., and J. Chakraborty. "Determinants of Reproductive Change in a Traditional Society: Evidence from Matlab, Bangladesh," Studies in Family Planning 19(6) (1988), 313-334.

Pitt, M. and S. Khandker. "The Impact of Group-Based Credit Programs on Poor Households in Bangladesh: Does the Gender of Participants Matter?" Journal of Political Economy 106 (1998), 958-995.

Pitt, M.M., Rosenzweig, M.R., and D. Gibbons. “The Determinants and Consequences of Placement of Government Programs in Indonesia," World Bank Economic Review 7 (1993): 319348.

Pollak, R. "Bargaining Power in Marriage: Earning, Wage Rates and Household Production," National Bureau of Economic Research Working Paper \#11239 (2005).

Pop-Eleches, K. "The Impact of a Change in Abortion Regime on Socio-Economic Outcomes of Children: Evidence from Romania," Journal of Political Economy (2006), forthcoming.

Pritchett, L.H. "Desired Fertility and the Impact of Population Policies," Population and Development Review 20(1) (1994), 1-55.

Rangel, M. "Alimony Rights and Intra-Household Allocation of Resources: Evidence from Brazil," BREAD Working Paper \#066 (2004).

Ribar, D.C. “The Socioeconomic Consequences of Young Women's Childbearing: Reconciling Disparate Evidence," Journal of Population Economics 12 (1999), 547-565.

Robey, B., Rutstein, S.O., and L. Morris. "The Fertility Decline in Developing Countries," Scientific American 269(6) (1993), 60-66.

Rogers, E.M. Diffusion of Innovations. New York: Free Press, 1962.

Rosenzweig, M.R. and K.I. Wolpin. "Testing the Quantity-Quality- Fertility Model: The Use of Twins as a Natural Experiment," Econometrica 48 (1980), 227-240.

Rosenzweig, M.R. and T.P. Schultz. "Market Opportunities, Genetic Endowments, and Intrafamily Resource Distribution: Child Survival in Rural India," American Economic Review 72 (1982), 803-815. 
Rosenzweig, M.R. and K.I. Wolpin. "Evaluating the Effects of Optimally Distributed Public Programs: Child Health and Family Planning Interventions," American Economic Review 76(3) (1986), 470-482.

Schultz, T.W. The Economics of the Family: Marriage, Children, and Human Capital. New York: National Bureau of Economic Research, 1974.

Schultz, T.P. "Human Capital, Family Planning, and Their Effects on Population Growth," American Economic Review Papers and Proceedings 84(2) (1994), 255-260.

Schultz, T.P. "Demand for Children in Low Income Countries," in Mark Rosenzweig and Oded Stark (eds.), Handbook of Population and Family Economics Volume 1A. Oxford: Elsevier Science, 1997.

Schultz, T.P. "Effects of Fertility Decline on Family Well-Being: Opportunities for Evaluating Population Programs," Mimeo, Yale University, 2005.

Seltzer, J. and F. Gomez. "Family Planning and Population Programs in Colombia 1965-1997," Population Technical Assistance Project (POPTECH) Report \#97-114-062 (1998).

Sen, A. “Missing Women,” British Medical Journal 304 (1992), 586-587.

Sinha, N. "Fertility, Child Work and Schooling Consequences of Family Planning Programs: Evidence from an Experiment in Rural Bangladesh," Yale University Economic Growth Center Discussion Paper \#867 (2003).

Singh, R. Family Planning Success Stories (Asia, Latin America, Africa). Delhi: UBS Publishers' Distributors Ltd., 1994.

Thomas, D. "Intra-household Resource Allocation: An Inferential Approach," Journal of Human Resources 25 (1990), 635-664.

Thomas, D. "Like Father, Like Son; Like Mother, Like Daughter: Parental Resources and Child Height," Journal of Human Resources 29(4) (1994), 950-988.

United Nations Population Fund. The State of World Population 2004: The Cairo Consensus at Ten - Population, Reproductive Health, and the Global Effort to End Poverty. New York: United Nations Population Fund, 2004.

United Nations Program on HIV/AIDS. 2004 Report on the Global AIDS Epidemic. Geneva: United Nations Program on HIV/AIDS, 2004.

Willis, R. "A New Approach to the Economic Theory of Fertility," Journal of Political Economy 81(2) (1973), S14-S64. 
Wolpin, K.I. "Determinants and Consequences of the Mortality and Health of Infants and Children," in Mark Rosenzweig and Oded Stark (eds.), Handbook of Population and Family Economics Volume 1A. Oxford: Elsevier Science, 1997. 
Figure 1: Total Fertility Rates in Latin America by Country and Quinquennia, 1955-60 to 1985-90

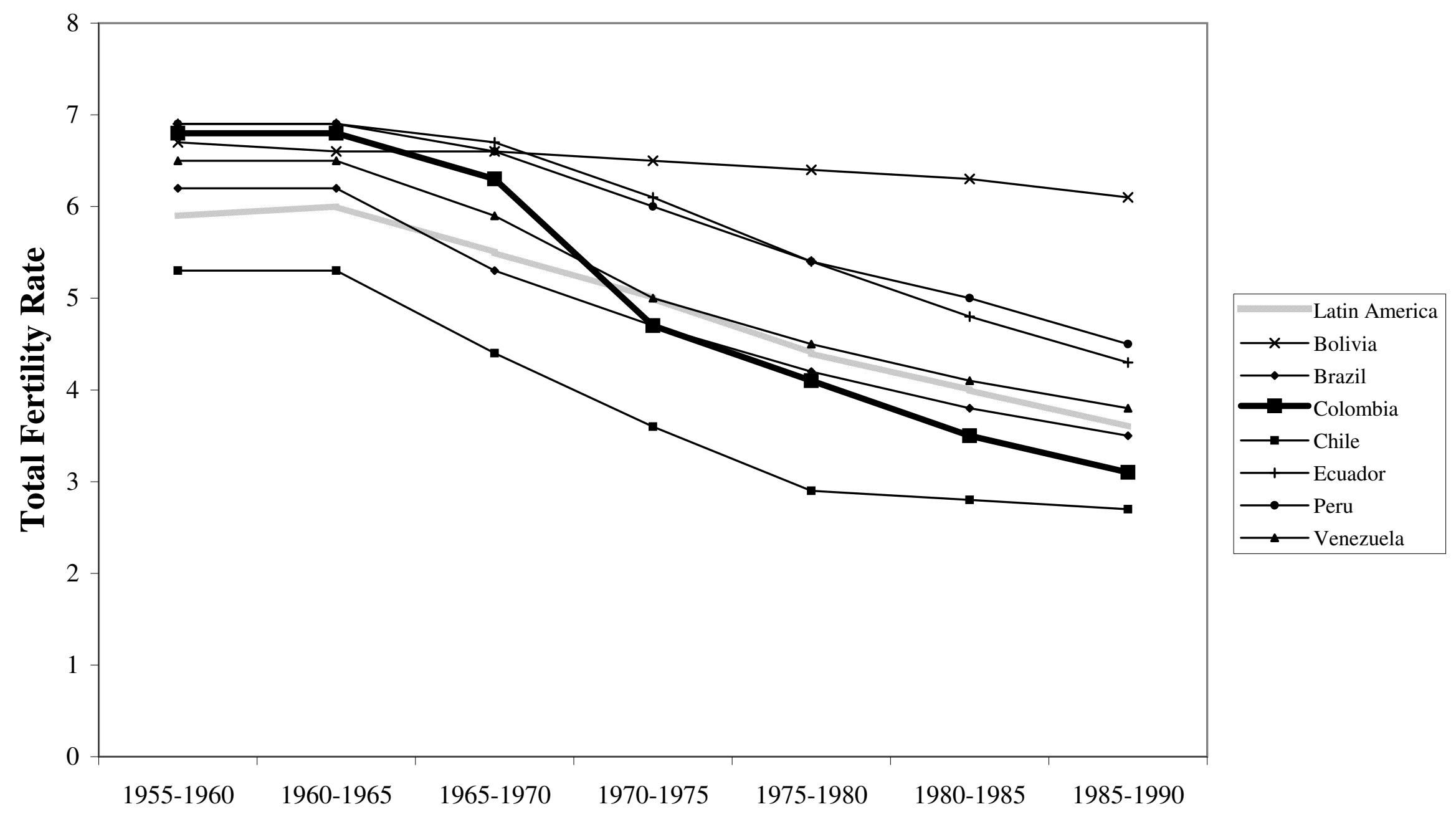

Source: Guzman, Singh, Rodriguez, and Pantelides (1996) 
Figure 2: Women's Lifetime Fertility by Birth Cohort and Program Group

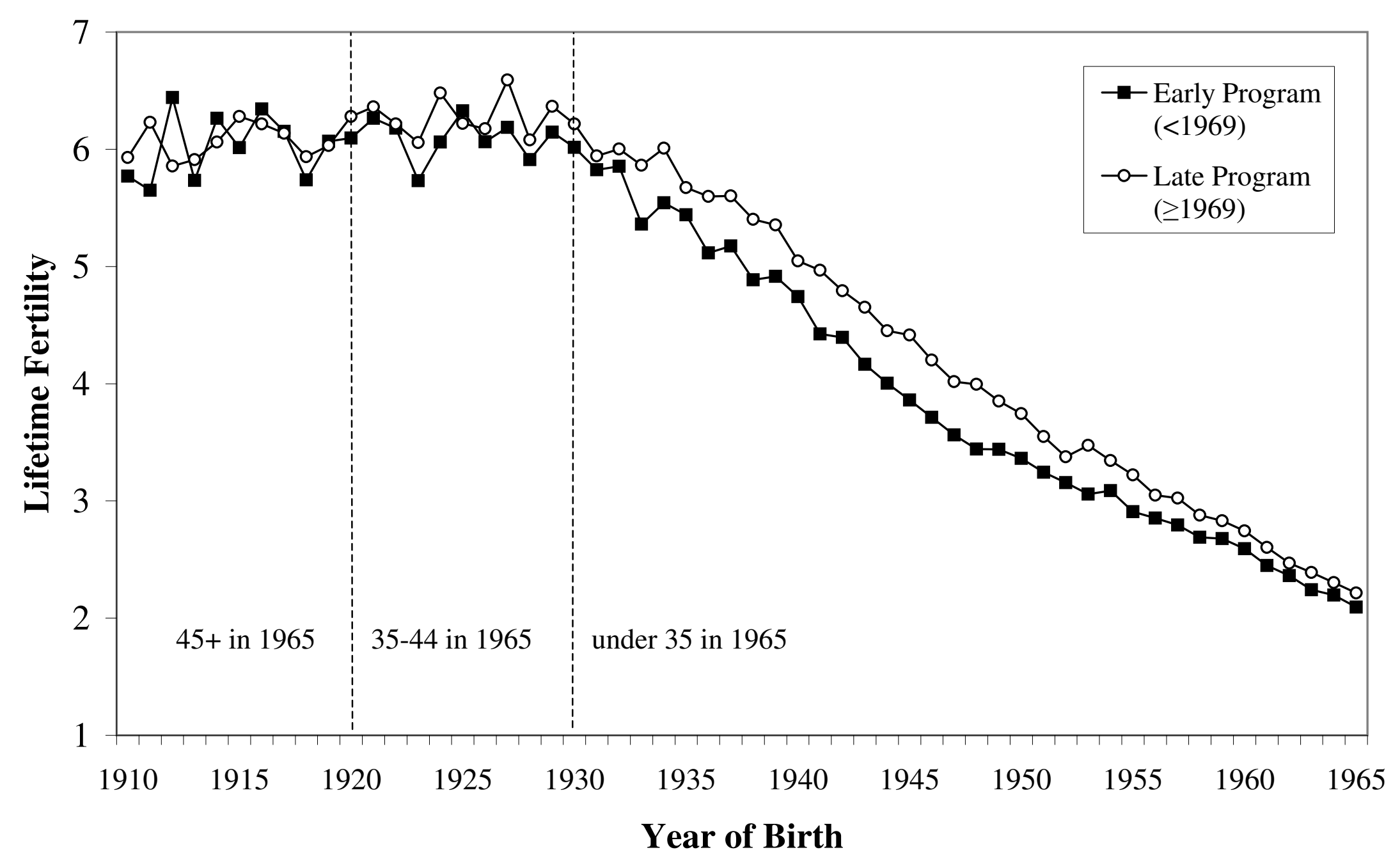


Figure 3: Women's Lifetime Fertility (Net of Cohort Effects)

by Age at First Access to Family Planning

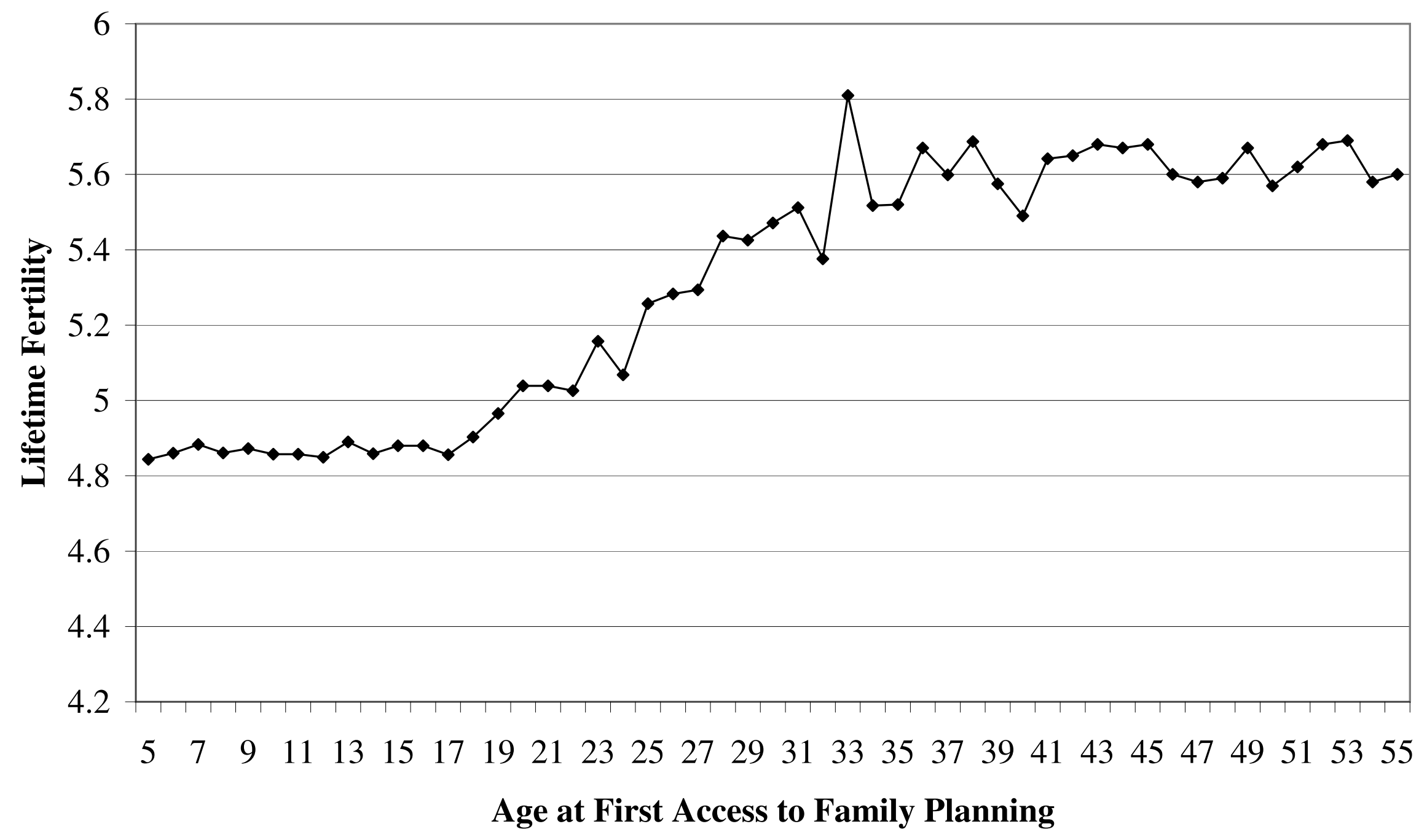


Table 1: Sample Descriptive Statistics, 1973 and 1993 Colombian Population Censuses

\begin{tabular}{|c|c|c|c|}
\hline & \multirow{2}{*}{$\frac{1973 \text { Census }}{\text { Total }}$} & \multicolumn{2}{|c|}{1993 Census } \\
\hline & & Total & Never-Movers \\
\hline Age & $\begin{array}{l}32.92 \\
(12.39)\end{array}$ & $\begin{array}{c}51.38 \\
(11.38)\end{array}$ & $\begin{array}{l}50.81 \\
(11.33)\end{array}$ \\
\hline Number of Children Ever Born & $\begin{array}{l}3.87 \\
(2.78)\end{array}$ & $\begin{array}{l}5.07 \\
(3.24)\end{array}$ & $\begin{array}{l}5.18 \\
(3.26)\end{array}$ \\
\hline Proportion of Children Dead if Ever Have Children & $\begin{array}{l}0.10 \\
(0.19)\end{array}$ & $\begin{array}{l}0.06 \\
(0.15)\end{array}$ & $\begin{array}{l}0.06 \\
(0.15)\end{array}$ \\
\hline Years of Education & N/A & $\begin{array}{l}5.29 \\
(3.43)\end{array}$ & $\begin{array}{l}5.32 \\
(3.49)\end{array}$ \\
\hline Share Ever Having Children & 0.65 & 0.88 & 0.86 \\
\hline Share Cohabitating & 0.56 & 0.32 & 0.30 \\
\hline Share Employed in the Formal Sector & 0.50 & 0.53 & 0.53 \\
\hline Share Always Living in Same Municipality & 0.73 & 0.60 & --- \\
\hline Share Moved in Past Five Years & 0.20 & 0.15 & --- \\
\hline
\end{tabular}

Note: Standard deviations shown in parentheses 
Table 2: Estimated Program Effects on Completed Lifetime Fertility Among Women Ever Having Children

\begin{tabular}{|c|c|c|c|c|}
\hline Dependent Variable: & $\ln$ (Births) & Any Birth & \multicolumn{2}{|c|}{\begin{tabular}{r|l} 
Births & Any Birth (NB2) \\
\end{tabular}} \\
\hline & Cohort Only & All Covariates & Cohort Only & All Covariates \\
\hline Family Planning Access 15-19 & $\begin{array}{c}-0.116^{* * * *^{\mathrm{B}}} \\
(0.012)\end{array}$ & $\begin{array}{c}-0.132 * * *^{\mathrm{B}} \\
(0.027)\end{array}$ & $\begin{array}{c}-0.064 * * *^{\mathrm{B}} \\
(0.004)\end{array}$ & $\begin{array}{c}-0.072^{* * * *^{\mathrm{B}}} \\
(0.012)\end{array}$ \\
\hline Family Planning Access 20-24 & $\begin{array}{c}-0.071^{* * * *^{\mathrm{B}}} \\
(0.018)\end{array}$ & $\begin{array}{c}-0.089 * * * *^{\mathrm{B}} \\
(0.022)\end{array}$ & $\begin{array}{c}-0.036 * * *^{\mathrm{B}} \\
(0.009)\end{array}$ & $\begin{array}{c}-0.042^{* * * *^{\mathrm{B}}} \\
(0.013)\end{array}$ \\
\hline Family Planning Access 25-29 & $\begin{array}{c}-0.054 * * *^{\mathrm{B}} \\
(0.016)\end{array}$ & $\begin{array}{c}-0.062 * * * \\
(0.025)\end{array}$ & $\begin{array}{c}-0.028 * * \\
(0.011)\end{array}$ & $\begin{array}{c}-0.038^{* * *} *^{\mathrm{B}} \\
(0.010)\end{array}$ \\
\hline Family Planning Access 30-34 & $\begin{array}{c}-0.030^{* * * *^{\mathrm{B}}} \\
(0.010)\end{array}$ & $\begin{array}{c}-0.042 * * *^{\mathrm{B}} \\
(0.010)\end{array}$ & $\begin{array}{l}-0.015^{*} \\
(0.009)\end{array}$ & $\begin{array}{c}-0.020 * * \\
(0.007)\end{array}$ \\
\hline Family Planning Access 35-39 & $\begin{array}{l}-0.021 \\
(0.017)\end{array}$ & $\begin{array}{l}-0.014 \\
(0.016)\end{array}$ & $\begin{array}{l}-0.011 \\
(0.023)\end{array}$ & $\begin{array}{l}-0.001 \\
(0.017)\end{array}$ \\
\hline Family Planning Access $40-44$ & $\begin{array}{l}-0.030 \\
(0.034)\end{array}$ & $\begin{array}{l}-0.033 \\
(0.048)\end{array}$ & $\begin{array}{l}-0.029 \\
(0.045)\end{array}$ & $\begin{array}{l}-0.002 \\
(0.036)\end{array}$ \\
\hline Family Planning Access 45-49 & $\begin{array}{l}-0.009 \\
(0.013)\end{array}$ & $\begin{array}{c}0.001 \\
(0.002)\end{array}$ & $\begin{array}{c}0.007 \\
(0.008)\end{array}$ & $\begin{array}{c}0.004 \\
(0.004)\end{array}$ \\
\hline Cohort Fixed-Effects & Yes & Yes & Yes & Yes \\
\hline Municipality Fixed-Effects & No & Yes & No & Yes \\
\hline Municipality-Specific Linear Trends & No & Yes & No & Yes \\
\hline $\mathrm{N}$ & 678,387 & 678,387 & 678,387 & 678,387 \\
\hline $\mathrm{R}^{2}$ & 0.40 & 0.40 & ----- & ------- \\
\hline
\end{tabular}

Notes: Standard errors clustered at the municipality level shown in parentheses. "Cohort Only" specifications include

birth cohort dummy variables; "All Covariates" include migration history, municipality dummies, cohort dummies, and municipality-specific linear time trends. ${ }^{*} \mathrm{p}<0.1, * * \mathrm{p}<0.05, * * * \mathrm{p}<0.01 .{ }^{\mathrm{B}}$ Significant $(\alpha=0.05)$ after a mutiple comparison

correction (the Bonferroni multiple comparison correction for six tests of significance requires a significance threshold

of $\alpha=0.0085$ for each test to recover an overall significance level of $\alpha=0.05$ ). 
Table 3: Estimated Program Effects on Probability of Ever Having a Child

\begin{tabular}{|c|c|c|c|}
\hline \multirow[t]{2}{*}{ Dependent Variable: } & \multicolumn{3}{|c|}{ Any Birth } \\
\hline & Cohort Only, 1993 Census & All Covariates, 1993 Census & All Covariates, 1973 Census \\
\hline Family Planning Access 15-19 & $\begin{array}{c}0.007 \\
(0.005)\end{array}$ & $\begin{array}{c}-0.001 \\
(0.008)\end{array}$ & $\begin{array}{c}-0.028 * * *^{\mathrm{B}} \\
(0.008)\end{array}$ \\
\hline Family Planning Access 20-24 & $\begin{array}{l}-0.005 \\
(0.003)\end{array}$ & $\begin{array}{c}0.009 \\
(0.006)\end{array}$ & $\begin{array}{c}-0.011^{*} \\
(0.006)\end{array}$ \\
\hline Family Planning Access 25-29 & $\begin{array}{c}-0.002 \\
(0.005)\end{array}$ & $\begin{array}{c}0.002 \\
(0.002)\end{array}$ & $\begin{array}{c}-0.004 \\
(0.004)\end{array}$ \\
\hline Family Planning Access 30-34 & $\begin{array}{c}-0.004 \\
(0.004)\end{array}$ & $\begin{array}{c}0.003 \\
(0.005)\end{array}$ & $\begin{array}{c}0.002 \\
(0.003)\end{array}$ \\
\hline Family Planning Access 35-39 & $\begin{array}{c}0.007 \\
(0.004)\end{array}$ & $\begin{array}{c}-0.009 \\
(0.007)\end{array}$ & $\begin{array}{l}-0.021 \\
(0.019)\end{array}$ \\
\hline Family Planning Access 40-44 & $\begin{array}{l}-0.011 \\
(0.014)\end{array}$ & $\begin{array}{c}0.017 \\
(0.013)\end{array}$ & $\begin{array}{c}-0.003 \\
(0.003)\end{array}$ \\
\hline Family Planning Access 45-49 & $\begin{array}{c}-0.012 \\
(0.008)\end{array}$ & $\begin{array}{c}-0.008 \\
(0.006)\end{array}$ & $\begin{array}{l}-0.007 \\
(0.005)\end{array}$ \\
\hline Cohort Fixed-Effects & Yes & Yes & Yes \\
\hline Municipality Fixed-Effects & No & Yes & Yes \\
\hline Municipality-Specific Linear Trends & No & Yes & Yes \\
\hline $\mathrm{N}$ & $1,064,874$ & $1,064,874$ & 798,392 \\
\hline $\mathrm{R}^{2}$ & 0.70 & 0.80 & 0.80 \\
\hline
\end{tabular}

Notes: The results shown are marginal probabilities obtained from probit models calculated at the mean of the independent variables. Standard errors clustered at the municipality level shown in parentheses. "Cohort Only" specifications include birth cohort dummy variables. "All Covariates" include migration history, municipality dummies, cohort dummies, and municipality-specific linear time trends. ${ }^{*} \mathrm{p}<0.1,{ }^{* *} \mathrm{p}<0.05,{ }^{* * *} \mathrm{p}<0.01{ }^{\mathrm{B}}$ Significant $(\alpha=0.05)$ after a mutiple comparison correction (the Bonferroni multiple comparison correction for six tests of significance requires a significance threshold of $\alpha=0.0085$ for each test to recover an overall significance level of $\alpha=0.05$ ). 


\section{Table 4: Estimated Program Effects on Socio-Economic Status Among Women Ever Having a Child}

\begin{tabular}{|c|c|c|c|c|c|}
\hline Dependent Variable: & Years of Education & Work in Formal Sector & "White-Collar" Job & Cohabitate & Share of Children Dead \\
\hline Family Planning Access 15-19 & $\begin{array}{c}0.142^{* * *^{\mathrm{B}}} \\
(0.048)\end{array}$ & $\begin{array}{c}0.027 * * *^{\mathrm{B}} \\
(0.007)\end{array}$ & $\begin{array}{c}0.019 \\
(0.015)\end{array}$ & $\begin{array}{c}-0.023 * * \\
(0.011)\end{array}$ & $\begin{array}{l}-0.002 \\
(0.002)\end{array}$ \\
\hline Family Planning Access 20-24 & $\begin{array}{c}0.067 * * \\
(0.031)\end{array}$ & $\begin{array}{c}0.033 * * *^{\mathrm{B}} \\
(0.009)\end{array}$ & $\begin{array}{c}0.009 \\
(0.013)\end{array}$ & $\begin{array}{c}-0.021 * * *^{\mathrm{B}} \\
(0.004)\end{array}$ & $\begin{array}{c}0.001 \\
(0.003)\end{array}$ \\
\hline Family Planning Access 25-29 & $\begin{array}{c}0.097 \\
(0.078)\end{array}$ & $\begin{array}{c}0.006 \\
(0.008)\end{array}$ & $\begin{array}{c}0.002 \\
(0.009)\end{array}$ & $\begin{array}{l}-0.008 \\
(0.006)\end{array}$ & $\begin{array}{l}0.003^{*} \\
(0.002)\end{array}$ \\
\hline Family Planning Access 30-34 & $\begin{array}{l}-0.012 \\
(0.083)\end{array}$ & $\begin{array}{c}0.009 \\
(0.011)\end{array}$ & $\begin{array}{l}-0.008 \\
(0.016)\end{array}$ & $\begin{array}{c}-0.014 * * \\
(0.007)\end{array}$ & $\begin{array}{l}-0.002 \\
(0.003)\end{array}$ \\
\hline Family Planning Access 35-39 & $\begin{array}{l}-0.026 \\
(0.033)\end{array}$ & $\begin{array}{l}-0.005 \\
(0.014)\end{array}$ & $\begin{array}{l}-0.013 \\
(0.016)\end{array}$ & $\begin{array}{c}0.010 \\
(0.008)\end{array}$ & $\begin{array}{l}-0.003 \\
(0.002)\end{array}$ \\
\hline Family Planning Access 40-44 & $\begin{array}{l}-0.011 \\
(0.064)\end{array}$ & $\begin{array}{c}-0.012 \\
(0.012)\end{array}$ & $\begin{array}{c}0.049 \\
(0.037)\end{array}$ & $\begin{array}{c}0.004 \\
(0.021)\end{array}$ & $\begin{array}{c}0.004 \\
(0.004)\end{array}$ \\
\hline Family Planning Access 45-49 & $\begin{array}{l}-0.016 \\
(0.048)\end{array}$ & $\begin{array}{c}0.011 \\
(0.019)\end{array}$ & $\begin{array}{l}-0.004 \\
(0.032)\end{array}$ & $\begin{array}{c}0.004 \\
(0.014)\end{array}$ & $\begin{array}{l}-0.002 \\
(0.003)\end{array}$ \\
\hline $\mathrm{N}$ & 669,446 & 631,784 & 169,285 & 643,854 & 624,399 \\
\hline $\mathrm{R}^{2}$ & 0.23 & 0.15 & 0.04 & 0.08 & 0.07 \\
\hline
\end{tabular}

Notes: The results shown for Work in Formal Sector, "White-Collar" Job, and Cohabitate are marginal probabilities obtained from probit models calculated at the mean of the independent variables. All specifications include migration history, municipality dummies, cohort dummies, and municipality-specific linear time trends. Standard errors clustered at the municipality level shown in parentheses. ${ }^{*} \mathrm{p}<0.1, * * \mathrm{p}<0.05, * * * \mathrm{p}<0.01$. ${ }^{\mathrm{B}}$ Significant $(\alpha=0.05)$ after a mutiple comparison correction (the Bonferroni multiple comparison correction for six tests of significance requires a significance threshold of $\alpha=0.0085$ for each test to recover an overall significance level of $\alpha=0.05$ ). 


\section{Table 5: Estimated Pre-Program Effects on Various Outcomes}

\begin{tabular}{|c|c|c|c|c|}
\hline & Estimate $^{\S}$ & Std Err & $\mathrm{N}$ & $\mathrm{R}^{2}$ \\
\hline \multicolumn{5}{|l|}{ Dependent Variable } \\
\hline Any Birth (1993 Census) & 0.004 & $(0.004)$ & 121,738 & 0.26 \\
\hline Number of Children if Any Birth (1993 Census) & 0.010 & $(0.010)$ & 104,413 & 0.08 \\
\hline Share of Children Dead if Any Birth (1993 Census) & 0.124 & $(0.234)$ & 104,413 & 0.01 \\
\hline Years of Education (1993 Census) & 0.026 & $(0.027)$ & 104,413 & 0.18 \\
\hline Cohabitate (1993 Census) & 0.002 & $(0.006)$ & 104,413 & 0.08 \\
\hline Work in the Formal Sector (1993 Census) & -0.003 & $(0.004)$ & 104,413 & 0.07 \\
\hline "White-Collar" Job if Work in Formal Sector (1993 Census) & 0.011 & $(0.034)$ & 36,458 & 0.20 \\
\hline Any Birth (1973 Census) & -0.001 & $(0.003)$ & 142,937 & 0.21 \\
\hline Number of Children if Any Birth (1973 Census) & 0.004 & $(0.005)$ & 128,294 & 0.09 \\
\hline Share of Children Dead if Any Birth (1973 Census) & 0.001 & $(0.002)$ & 128,294 & 0.04 \\
\hline Cohabitate (1973 Census) & 0.002 & $(0.004)$ & 128,294 & 0.09 \\
\hline Work in the Formal Sector (1973 Census) & 0.003 & $(0.003)$ & 128,294 & 0.08 \\
\hline
\end{tabular}

Notes: The results shown for Any Birth, Cohabitate, Work in Formal Sector, and "White-Collar" Job are marginal probabilities obtained from probit models calculated at the mean of the independent variables. All specifications include migration history, municipality dummies, cohort dummies, and municipality-specific linear time trends. Census year (1973 or 1993) shown in parentheses next to each dependent variable. Standard errors clustered at the municipality level shown in parentheses. ${ }^{8}$ Estimates are for those $45-49$ when family planning programs began (relative to those 50-54) except for years of education, which is for those 25-29 when programs began (relative to those $30-34$ ). ${ }^{*} \mathrm{p}<0.1,{ }^{* *} \mathrm{p}<0.05$, $* * * \mathrm{p}<0.01$ 
Table 6: Estimated Program Effects on Socio-Economic Status Among Women Never Having a Child

\begin{tabular}{|c|c|c|c|c|}
\hline Dependent Variable: & Years of Education & Work in Formal Sector & "White-Collar" Job & Cohabitate \\
\hline Family Planning Access 15-19 & $\begin{array}{c}0.046 \\
(0.167)\end{array}$ & $\begin{array}{c}0.010 \\
(0.014)\end{array}$ & $\begin{array}{c}0.005 \\
(0.029)\end{array}$ & $\begin{array}{l}-0.002 \\
(0.010)\end{array}$ \\
\hline Family Planning Access 20-24 & $\begin{array}{c}-0.071 \\
(0.144)\end{array}$ & $\begin{array}{c}-0.010 \\
(0.017)\end{array}$ & $\begin{array}{c}0.037 \\
(0.031)\end{array}$ & $\begin{array}{c}-0.016 \\
(0.013)\end{array}$ \\
\hline Family Planning Access 25-29 & $\begin{array}{c}-0.306 \\
(0.182)\end{array}$ & $\begin{array}{c}0.007 \\
(0.028)\end{array}$ & $\begin{array}{c}0.046 \\
(0.067)\end{array}$ & $\begin{array}{c}0.012 \\
(0.020)\end{array}$ \\
\hline Family Planning Access 30-34 & $\begin{array}{c}0.309 \\
(0.230)\end{array}$ & $\begin{array}{c}0.006 \\
(0.025)\end{array}$ & $\begin{array}{c}-0.008 \\
(0.017)\end{array}$ & $\begin{array}{c}0.018 \\
(0.017)\end{array}$ \\
\hline Family Planning Access 35-39 & $\begin{array}{l}-0.050 \\
(0.034)\end{array}$ & $\begin{array}{c}-0.004 \\
(0.010)\end{array}$ & $\begin{array}{c}-0.024 \\
(0.079)\end{array}$ & $\begin{array}{c}-0.021 \\
(0.021)\end{array}$ \\
\hline Family Planning Access 40-44 & $\begin{array}{l}-0.010 \\
(0.092)\end{array}$ & $\begin{array}{c}-0.012 \\
(0.045)\end{array}$ & $\begin{array}{c}0.139 \\
(0.136)\end{array}$ & $\begin{array}{c}-0.003 \\
(0.036)\end{array}$ \\
\hline Family Planning Access 45-49 & $\begin{array}{c}0.025 \\
(0.068)\end{array}$ & $\begin{array}{c}-0.026 \\
(0.041)\end{array}$ & $\begin{array}{c}-0.002 \\
(0.120)\end{array}$ & $\begin{array}{c}-0.050 \\
(0.031)\end{array}$ \\
\hline $\mathrm{N}$ & 191,433 & 186,829 & 47,128 & 188,763 \\
\hline $\mathrm{R}^{2}$ & 0.67 & 0.15 & 0.08 & 0.07 \\
\hline
\end{tabular}

Notes: The results shown for Work in Formal Sector, "White-Collar" Job, and Cohabitate are marginal probabilities obtained from probit models calculated at the mean of the independent variables. All specifications include migration history, municipality dummies, cohort dummies, and municipality-specific linear time trends. Standard errors clustered at the municipality level shown in parentheses. ${ }^{*} \mathrm{p}<0.1,{ }^{* *} \mathrm{p}<0.05, * * * \mathrm{p}<0.01$ 
Table 7: Estimated Program Effects on Fertility and Socioeconomic Outcomes Among Never-Movers

\begin{tabular}{|c|c|c|c|c|c|c|c|}
\hline Dependent Variable: & \begin{tabular}{l|l|}
$\ln ($ Births $)$ & Any Birth \\
\end{tabular} & \begin{tabular}{l|l} 
Births & Any Birth (NB) \\
\end{tabular} & Any Birth & Years of Education & Work in Formal Sector & "White-Collar" Job & Cohabitate \\
\hline Family Planning Access 15-19 & $\begin{array}{c}-0.118^{* * *} *^{\mathrm{B}} \\
(0.026)\end{array}$ & $\begin{array}{c}-0.064 * * *^{\mathrm{B}} \\
(0.016)\end{array}$ & $\begin{array}{c}0.001 \\
(0.005)\end{array}$ & $\begin{array}{c}0.114 * * *^{\mathrm{B}} \\
(0.036)\end{array}$ & $\begin{array}{c}0.020 * * *{ }^{\mathrm{B}} \\
(0.005)\end{array}$ & $\begin{array}{l}-0.007 \\
(0.017)\end{array}$ & $\begin{array}{c}-0.032 * * *^{\mathrm{B}} \\
(0.009)\end{array}$ \\
\hline Family Planning Access 20-24 & $\begin{array}{c}-0.076^{* * * \mathrm{~B}} \\
(0.019)\end{array}$ & $\begin{array}{c}-0.043 * * *^{\mathrm{B}} \\
(0.013)\end{array}$ & $\begin{array}{c}0.012 \\
(0.008)\end{array}$ & $\begin{array}{c}0.058^{* *} \\
(0.024)\end{array}$ & $\begin{array}{c}0.037 * * *^{\mathrm{B}} \\
(0.010)\end{array}$ & $\begin{array}{l}-0.005 \\
(0.021)\end{array}$ & $\begin{array}{c}-0.020 * * \\
(0.009)\end{array}$ \\
\hline Family Planning Access 25-29 & $\begin{array}{c}-0.041 * * * \\
(0.013)\end{array}$ & $\begin{array}{c}-0.031 * * \\
(0.014)\end{array}$ & $\begin{array}{c}0.008 \\
(0.006)\end{array}$ & $\begin{array}{c}0.038 \\
(0.035)\end{array}$ & $\begin{array}{l}-0.007 \\
(0.010)\end{array}$ & $\begin{array}{c}0.000 \\
(0.023)\end{array}$ & $\begin{array}{l}-0.015 \\
(0.011)\end{array}$ \\
\hline Family Planning Access 30-34 & $\begin{array}{l}-0.032 \\
(0.018)\end{array}$ & $\begin{array}{c}0.002 \\
(0.018)\end{array}$ & $\begin{array}{c}0.006 \\
(0.006)\end{array}$ & $\begin{array}{c}0.016 \\
(0.024)\end{array}$ & $\begin{array}{l}-0.018 \\
(0.012)\end{array}$ & $\begin{array}{c}0.006 \\
(0.028)\end{array}$ & $\begin{array}{c}0.001 \\
(0.009)\end{array}$ \\
\hline Family Planning Access 35-39 & $\begin{array}{c}0.018 \\
(0.024)\end{array}$ & $\begin{array}{c}0.015 \\
(0.019)\end{array}$ & $\begin{array}{c}0.004 \\
(0.008)\end{array}$ & $\begin{array}{l}-0.043 \\
(0.057)\end{array}$ & $\begin{array}{l}-0.020 \\
(0.016)\end{array}$ & $\begin{array}{c}0.026 \\
(0.049)\end{array}$ & $\begin{array}{l}-0.005 \\
(0.012)\end{array}$ \\
\hline Family Planning Access 40-44 & $\begin{array}{l}-0.028 \\
(0.039)\end{array}$ & $\begin{array}{l}-0.009 \\
(0.007)\end{array}$ & $\begin{array}{c}0.017 \\
(0.014)\end{array}$ & $\begin{array}{l}-0.031 \\
(0.093)\end{array}$ & $\begin{array}{l}-0.028 \\
(0.026)\end{array}$ & $\begin{array}{c}0.002 \\
(0.008)\end{array}$ & $\begin{array}{c}0.014 \\
(0.033)\end{array}$ \\
\hline Family Planning Access 45-49 & $\begin{array}{c}0.042 \\
(0.035)\end{array}$ & $\begin{array}{l}-0.012 \\
(0.021)\end{array}$ & $\begin{array}{c}0.015 \\
(0.012)\end{array}$ & $\begin{array}{c}0.026 \\
(0.025)\end{array}$ & $\begin{array}{l}-0.020 \\
(0.021)\end{array}$ & $\begin{array}{c}0.009 \\
(0.009)\end{array}$ & $\begin{array}{c}0.008 \\
(0.019)\end{array}$ \\
\hline $\mathrm{N}$ & 413,833 & 413,833 & 651,184 & 409,217 & 386,474 & 112,377 & 394,756 \\
\hline $\mathrm{R}^{2}$ & 0.41 & ------ & 0.82 & 0.26 & 0.13 & 0.05 & 0.08 \\
\hline
\end{tabular}

Notes: The results shown for Any Birth, Cohabitate, Work in Formal Sector, and "White-Collar" Job are marginal probabilities obtained from probit models calculated at the mean of the independent variables. All specifications include migration history, municipality dummies, cohort dummies, and municipality-specific linear time trends. Standard errors clustered at the municipality level shown in parentheses. ${ }^{*} \mathrm{p}<0.1,{ }^{* *} \mathrm{p}<0.05,{ }^{* * *} \mathrm{p}<0.01 .{ }^{\mathrm{B}} \mathrm{Significant}(\alpha=0.05)$ after a mutiple comparison correction (the Bonferroni multiple comparison correction for six tests of significance requires a significance threshold of $\alpha=0.0085$ for each test to recover an overall significance level of $\alpha=0.05$ ). 
Table 8: Estimated Effects of Mother's Lifetime Family Planning Access on Child Socio-Economic Status

\begin{tabular}{|c|c|c|c|}
\hline Dependent Variable: & Attending School & Work in Formal Sector & Years of Education \\
\hline Mother's Access 15-19 (Boys and Girls) & $\begin{array}{c}0.019 * * * \\
(0.007)\end{array}$ & $\begin{array}{c}-0.016 * * \\
(0.008)\end{array}$ & $\begin{array}{c}0.077 * * * \\
(0.021)\end{array}$ \\
\hline Mother's Access 15-19 (Boys Only) & $\begin{array}{c}0.033 * * * \\
(0.009)\end{array}$ & $\begin{array}{c}-0.091 * * * \\
(0.010)\end{array}$ & $\begin{array}{c}0.090 * * * \\
(0.029)\end{array}$ \\
\hline Mother's Access 15-19 (Girls Only) & $\begin{array}{c}0.007 \\
(0.006)\end{array}$ & $\begin{array}{c}0.047 * * \\
(0.021)\end{array}$ & $\begin{array}{c}0.066 * * \\
(0.031)\end{array}$ \\
\hline
\end{tabular}

Notes: Each cell is obtained from a different regression and shows an estimate for statistical mother family planning access beginning at ages 15-19 (relative to no access at reproductive ages). The results shown for Attending School and Work in Formal Sector are marginal probabilities obtained from probit models calculated at the mean of the independent variables. All specifications also include statistical mother's age, statistical mother's migration history, municipality dummies, cohort dummies, and municipality-specific linear trends.

Standard errors clustered at the municipality level are shown in parentheses. ${ }^{*} \mathrm{p}<0.1, * * \mathrm{p}<0.05, * * * \mathrm{p}<0.01$. 